\title{
Química, Tablets e Telemóveis Inteligentes: Prémios Nobel da Química 1901-2011 em Código QR
}

\author{
Vasco D. B. Bonifácio \\ REQUIMTE, Departamento de Química, Faculdade de Ciências e Tecnologia, \\ Universidade Nova de Lisboa \\ vbb@fct.unl.pt
}

O Prémio Nobel é o prémio mais prestigioso do mundo. Usando ferramentas gratuitas e de fácil acesso é possível obter informação codificada sobre todos os Prémios Nobel da Química entre 1901 e 2011. Esta informação, compilada numa tabela cronológica sob a forma de códigos QR, permite a introdução desta temática na sala de aula usando um telemóvel inteligente ou um tablet.

O Prémio Nobel é sem dúvida o mais ambicionado prémio a nível mundial. Muitos são aqueles que trabalham e sonham com a possibilidade de um dia poderem vir a ser agraciados com tão elevada distinção. Instituído em 1901, por desejo de Alfred Nobel num testamento de 1895, este prémio tem hoje o valor monetário de 1 milhão de euros. Alfred Nobel foi sobretudo um inventor, e o seu interesse por Química e Engenharia levaram-no a fazer uma descoberta que modificou radicalmente o mundo que conhecemos. Foi ele que inventou a dinamite, um material explosivo feita à base de nitroglicerina (Figura 1), e o detonador. Esta descoberta e outras relacionadas com a indústria de tecnologia de explosivos conduziram-no à escrita de 355 patentes.

Os Prémios Nobel têm vindo a ser atribuídos regularmente desde 1901 nas áreas da Química, da Física, da Medicina, da Literatura, da Paz e, posteriormente (a partir de 1968), na área das Ciências Económicas. Contudo, devido a razões especiais, tais como as $1^{\mathrm{a}}$ e $2^{\mathrm{a}}$ Guerras Mundiais, não foram atribuídos nos anos de 1916, 1917, 1919, 1924, 1933, 1940, 1941 e 1942.

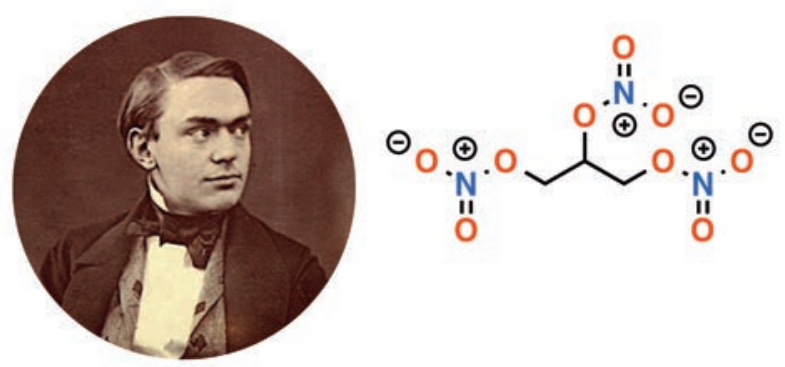

Figura 1 - Retrato do jovem Alfred Nobel e estrutura química da nitroglicerina, composto base da dinamite

No período de 1901 a 2011 (Ano Internacional da Química) o Prémio Nobel da Química foi atribuído a 160 cientistas. Na realidade o prémio foi atribuído 161 vezes, dado que Frederic Sanger (recentemente falecido, 13 Agosto 1918 - 19 Novembro 2013) recebeu o prémio duas vezes, em 1958 e em 1980.
Não deixa de ser curiosa a ausência quase total de mulheres distinguidas com este prémio. Apenas 4 mulheres (2,5\%) foram até ao momento reconhecidas pelo seu trabalho inovador no domínio da Química, uma ciência onde as mulheres se encontram muito mais representadas que os homens [1-3]. As mulheres cientistas distinguidas com o Prémio Nobel da Química foram Marie Curie (1911, também Prémio Nobel da Física em 1903), a sua filha Irène Juliot-Curie (1935), Dorothy Hodgkin (1964) e mais recentemente Ada Yonath (2009).

A análise da distribuição do Prémio Nobel pelas diversas áreas da Química permite-nos concluir que a Química Orgânica (44 prémios, 27,3\%) e a Bioquímica (43 prémios, 26,7\%) são as mais contempladas, seguidas da Química-Física (30 prémios, 18,6\%) e a Química Inorgânica e Nuclear (18 prémios, 11,2\%).

A (r)evolução tecnológica a que temos vindo a assistir na última década mudou definitivamente o Ensino dito clássico. Na sala de aula, o quadro de ardósia e o pau de giz deram lugar a ecrãs multimédia e vibrantes apresentações em powerpoint.

Em muitos países os telemóveis inteligentes e os tablets são já parte integrante das novas metodologias de ensino baseadas em conteúdos electrónicos, tais como o mobile-learning. A estratégia do m-learning tem sido alvo de alguma polémica, contudo os resultados indicam que de facto é possível aumentar o interesse dos alunos pelas matérias leccionadas recorrendo a jogos educacionais (gamification) usando informação codificada, em especial usando códigos QR [4]. Nos últimos anos têm vindo a ser desenvolvidas ferramentas educacionais recorrendo a estes códigos [5], em especial na área da Química [6-8].

Com o objectivo de enriquecer os educadores com ferramentas de m-learning no domínio da Química foi recentemente construído um poster contendo todos os Prémios Nobel da Química entre 1901 e 2011, ordenados de forma cronológica [9]. Os laureados estão associados a um código QR e a uma cor representativa da sua área de investigação.

As cores escolhidas foram o verde (Química Orgânica), o azul (Bioquímica), o laranja (Química-Física) e o rosa (Química Inorgânica e Nuclear). O poster contem igualmente um código QR que dirige os alunos para um questionário que testa os seus conhecimentos acerca de Alfred Nobel (Figura 2). 


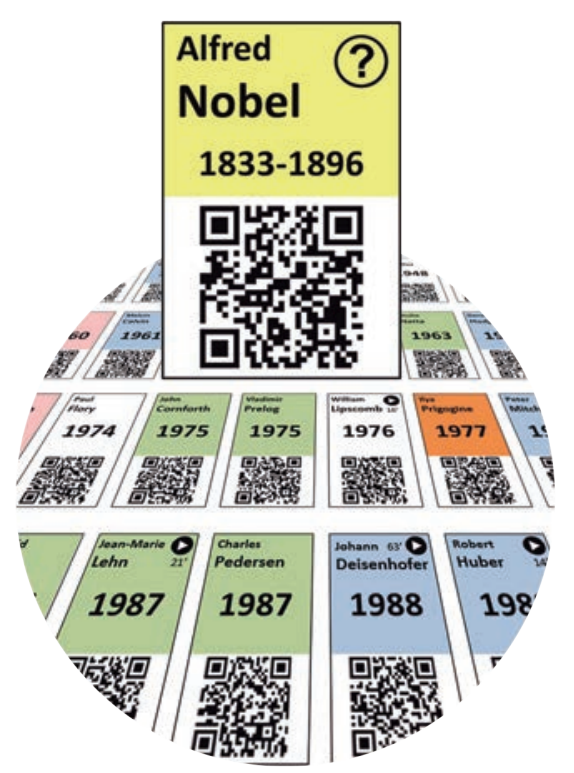

Figura 2 - Códigos QR no Ensino da Química. Tabela cronológica dos Prémios Nobel da Química e questionário sobre Alfred Nobel. A leitura dos códigos QR, usando um telemóvel inteligente ou um tablet, dirige automaticamente os alunos para a respectiva página na internet

Este poster foi desenvolvido para introduzir a temática dos Prémios Nobel na sala de aula, de forma interactiva. Após uma breve introdução sobre Alfred Nobel e o seu legado, o educador poderá dar início ao "jogo” usando o código QR apresentado no poster e que dirige os alunos para um questionário (em língua inglesa). Os alunos poderão também explorar aleatoriamente os códigos QR dos Prémios Nobel, usando o poster ou cartões distribuídos pelo educador, que os dirigem para a biografia e as descobertas científicas dos laureados (disponibilizadas no site oficial dos Prémios Nobel). Este jogo, realizado em grupo ou individualmente, pode ser também usado em actividades extra-curriculares.

\section{AgRADECIMENTOS}

A elaboração do poster contendo os Prémios Nobel da Química 1901-2011 foi realizada com o suporte técnico da QRandGO ${ }^{\circledR}$.

\section{REFERÊNCIAS}

[1] M. Wutte, Nature 448 (2007) 101-102

[2] K. Powell, Nature 448 (2007) 98-100

[3] H. Hoag, Nature 459 (2009) 1021

[4] A.J. Williams, H.E. Pence, J. Chem. Educ. 88 (2011) 683-686

[5] G.M. Battle, G.O. Kyd, C. R. Groom, F. H. Allen, J. Day, T. Upson, J. Chem. Educ. 89 (2012) 1390-1394

[6] V.D.B. Bonifácio, J. Chem. Educ. 89 (2012) 552-554

[7] V.D.B. Bonifácio, Química - Boletim da SPQ 127 (2012) 71-72

[8] L. Benedict, H.E. Pence, J. Chem. Educ. 89 (2012) 492$-496$

[9] V.D.B. Bonifácio, J. Chem. Educ. 90 (2013) 1401-1402. O poster contendo os códigos QR com informação sobre os Prémios Nobel da Química entre 1901 e 2011 é disponibilizado de forma gratuita na informação suporte do artigo. (http://bit.ly/NPchem)

\section{Actualidades Cientificas}

\section{CÉLULAS ARTIFICIAIS COM ORGANELOS ACTIVOS}

No Institute for Molecules and Materials da Radboud University Nijmegen (Holanda), foi obtida a primeira célula artificial contendo organelos capazes de realizar reacções químicas. Numa célula viva, uma entidade pequena com vários "compartimentos", ocorre um conjunto grande de reacções químicas complexas, de forma altamente eficiente. Embora seja difícil reproduzir em laboratório a química envolvida nas células vivas, os químicos tentam imitar a célula, esperando aprender mais sobre a origem da vida e a transição da química para a biologia.

Os investigadores envolvidos no projecto criaram uma célula artificial a partir de nano-reactores poliméricos contendo enzimas, encapsulados conjuntamente com enzimas livres e substratos num grande polimersoma, formando uma estrutura multicompartimentada que apresenta semelhança estrutural com uma célula e seus organelos. Estudos de fluorescência mostraram que a cascata de reacções observada correspondeu ao que tinha sido previsto. A criação de estruturas semelhantes a células é um tema actual na área da química, tendo sido testados vários métodos neste Instituto holandês. Os Professores Wilhelm Huck e Van Hest referem que "Grupos de investigação concorrentes estão a trabalhar na formação de células a partir de ácidos gordos, por exemplo. Nós gostaríamos de fazer o mesmo no futuro”. Referem ainda que "Outro passo seria a obtenção de células produtoras da sua própria energia. Também estamos a trabalhar em formas de controlar o movimento de substâncias químicas dentro da célula. Com estas simulações seremos capazes de entender melhor as células vivas e um dia iremos mesmo ser capazes de fazer algo que se pareça muito com a realidade...".

(adaptado de http://www.sciencedaily.com/releases/2014/01/140114091707.htm; http://www.ru.nl/english/university/ vm/news/@929865/first-plastic-cell/ e de J.R. Ruud et al., Angew. Chem, Int. Ed., 53 (2014) 146 (DOI: 10.1002/ anie.201308141) e R. Johnson, Nature Chemistry 6 (2013) 5 (DOI: 10.1038/nchem.1840))

Paulo Mendes (pjgm@uevora.pt) 